\title{
SOIL FUNCTIONING IN A TOPOSEQUENCE UNDER RAINFOREST IN SÃO PAULO, BRAZIL ${ }^{(1)}$
}

\author{
Miguel Cooper ${ }^{(2)}$, João Carlos Medeiros ${ }^{(3)}$, Jaqueline Dalla Rosa ${ }^{(3)}$, José Eduardo Soria ${ }^{(4)}$ \\ \& Raul Shiso Toma ${ }^{(5)}$
}

\begin{abstract}
SUMMARY
Studies of soil-water dynamics using toposequences are essential to improve the understanding of soil-water-vegetation relationships. This study assessed the hydro-physical and morphological characteristics of soils of Atlantic Rainforest in the Parque Estadual de Carlos Botelho, state of São Paulo, Brazil. The study area of 10.24 ha $(320 \times 320 \mathrm{~m})$ was covered by dense tropical rainforest (Atlantic Rainforest). Based on soil maps and topographic maps of the area, a representative transect of the soil in this plot was chosen and five soil trenches were opened to determine morphological properties. To evaluate the soil hydro-physical functioning, soil particle size distribution, bulk density $(\rho)$, particle density $\left(\rho_{s}\right)$, soil water retention curves (SWRC), field saturated hydraulic conductivity (Ks), macroporosity (macro), and microporosity (micro) and total porosity (TP) were determined. Undisturbed samples were collected for micromorphometric image analysis, to determine pore size, shape, and connectivity. The soils in the study area were predominantly Inceptisols, and secondly Entisols and Epiaquic Haplustult. In the soil hydrophysical characterization of the selected transect, a change was observed in Ks between the surface and subsurface layers, from high/intermediate to intermediate/low permeability. This variation in soil-water dynamics was also observed in the SWRC, with higher water retention in the subsurface horizons. The soil hydro-physical behavior was influenced by the morphogenetic characteristics of the soils.
\end{abstract}

Index terms: soil physics, soil water retention curve, image analysis.

(1) Suported by FAPESP for financial support by the BIOTA/FAPESP Program - The Virtual Institute of Biodiversity. Received for publication on May 23, 2012 and approved on February 5, 2013.

(2) Professor, Departamento Ciência do Solo, Escola Superior de Agricultura "Luiz de Queiroz", Universidade de São Paulo. Av.a Pádua Dias, 11. CEP 13418-900 Piracicaba (SP). E-mail: mcooper@usp.br

(3) Pós doutorando, Embrapa Arroz e Feijão - CNPAF. Rodovia GO-462, km 12, Zona Rural. Caixa Postal 179. CEP 75375-000 Santo Antônio de Goiás (GO). E-mail: jaqueline.dr@gmail.com; medeiros.jc@gmail.com;

(4) Agronomist, Centro de Tecnologia Canavieira. Fazenda Santo Antônio, s/n. Santo Antonio. Caixa Postal 162. CEP 13400-970 Piracicaba (SP). E-mail: jsoria@ctc.com.br

(5) Pós doutorando, Universidad Nacional de Río Cuarto. Ruta Nac. 36, km. 601. Río Cuarto IV Córdoba ,Argentina. E-mail: raulst@esalq.usp.br 


\title{
RESUMO: FUNCIONAMENTO DO SOLO EM UMA TOPOSSEQUÊNCIA SOB MATA ATLÂNTICA EM SÃO PAULO, BRASIL
}

\begin{abstract}
O estudo da dinâmica da água no solo utilizando topossequências é de grande importância para melhor compreender as relações solo-água-vegetação. Objetivou-se, com este trabalho, caracterizar físico, hídrica e morfologicamente os solos da mata do Parque Estadual de Carlos Botelho. A parcela abrange uma área de 10,24 ha (320 x $320 \mathrm{~m})$, localizada sob Floresta Ombrófila Densa (Mata Atlântica de Encosta). Com base nos mapas de solos ultradetalhados e mapas planialtimétricos dessa área, escolheu-se uma transeção representativa dos solos da parcela; nessa, foram abertas cinco trincheiras, onde foi feita a descrição morfológica dos diferentes horizontes dos solos. No estudo da dinâmica da água no solo, foram feitas análises granulométricas, de densidade do solo e partículas, de curvas de retenção e de medidas de condutividade hidráulica saturada no campo, utilizando-se o permeâmetro de Guelph. Coletaram-se amostras indeformadas para realizar análises de imagens. Os Cambissolos apresentaram-se como os solos predominantes na parcela, mas também foram encontradas manchas de Neossolos e Gleissolos. No estudo da caracterização físico-hídrica dos solos da topossequência escolhida, observou-se mudança na condutividade hidráulica entre as camadas superficiais e subsuperficiais, de alta/intermediária para intermediária/baixa permeabilidade. Essa variação do comportamento da água no solo também pôde ser observada nas curvas de retenção de água, que evidenciou maior retenção de água nos horizontes subsuperficiais. Fatores como porosidade total, dimensão, forma e conexão entre os poros foram analisados por meio da análise de imagens. O comportamento físico-hídrico dos solos foi influenciado pelas características morfogênicas do solo.
\end{abstract}

Termos de indexação: física do solo, curva de retenção de água do solo, análise de imagens.

\section{INTRODUCTION}

The soil hydro-physical characterization is an important tool to comprehend the dynamics of water fluxes in the soil, deepening the understanding of water behavior and its availability to plants. The qualitative and quantitative assessment of hydro-physical soil properties can explain the relationships between soil, water, and vegetation, permitting the evaluation of how the soil affects native vegetation and vice versa. Studying the hydro-physical behavior of soils in a toposequence in the municipality of Assis (SP, Brazil), Juhász et al. (2006) observed low water availability and associated the predominant vegetation type (savanna woodland, Cerradão) with the condition of water deficiency.

Hydraulic conductivity provides important information about the hydraulic behavior of a soil and allows the characterization of the water flow in the soil profile, distinguishing conductivity through macropores from the water movement in the soil matrix (Perroux \& White, 1988; Vauclin et al., 1993). Hydraulic conductivity may be influenced by several factors, including total porosity and pore structure (pore size, shape and connectivity), which are quantifiable (Diab et al., 1988; Hallaire et al., 1998).

The combination of different soil analysis with micromorphological studies allows the synthesis and integration of soil data at multiple scales, including several levels of soil organization (Miedema, 1997), from landscape to soil microstructure (Castro et al., 2003). Pore size is usually determined in relation to the matric potential, tested through mathematical calculations, and shape and pore connectivity can be obtained by soil image analysis. This characterization of the soil pore space using micromorphometrical analysis can provide detailed information on the soil structure conditions, especially when the agronomic and management conditions are known. Furthermore, this analysis is also used to assess the physical vulnerability of the soil and to interpret soil behavior and dynamics (Castro et al., 2003).

Based on the hypothesis that the understanding of soil functioning under native forest is essential for the preservation and restoration of native ecosystems, the objective of this study was to characterize the hydro-physical properties of soils of a toposequence in the Carlos Botelho State Park, SP, Brazil, to deepen the understanding about the relationship between soil functions and hydro-physical dynamics.

\section{MATERIAL AND METHODS}

\section{Description of the study area}

The study was conducted in the Carlos Botelho State Park, which has a total area of approximately 40.000 ha of dense ombrophilous rainforest. The park is located in the south of the State of São Paulo $\left(24^{\circ}\right.$ $00^{\prime}-24^{\circ} 15^{\prime} \mathrm{S}$ and $47^{\circ} 45^{\prime}-48^{\circ} 10^{\prime} \mathrm{W}$, at 30 to $1,003 \mathrm{~m}$ asl). Granite rocks predominate in the park, forming a highly rugged topography. This topography can be separated in areas of two different climate types, 
according to the Köppen (1948) classification: 1) a hot humid climate without a dry season (Cfa) below 800 $\mathrm{m}$, and 2) a humid temperate climate without a dry season $(\mathrm{Cfb})$ in the higher regions of the Paranapiacaba mountain range.

A plot of 10.24 ha was outlined based on topographic surveys and was subdivided into 256 subplots of $20 \times 20 \mathrm{~m}$. A transect that included the most representative soils of the area was chosen using the soil maps of the plot. Pits were opened at a depth of $1.5 \mathrm{~m}$ in the main soils of this transect. The soil morphology was described using the methodology proposed by Lemos \& Santos (2002).

\section{Transect characterization, determination of organic carbon and soil physical analysis}

The soil distribution and the horizon geometry along the transect were defined using the structural analysis methodology proposed by Boulet et al. (1982). Disturbed samples were collected from each horizon and from the profiles to determine the particle size distribution (Gee $\&$ Bauder, 1986), particle density $\left(\rho_{\mathrm{s}}\right)$ (Vomocil, 1965) and soil organic carbon (OC). The OC was obtained through oxidation, reducing the $\mathrm{Cr}$ (III) ions of potassium dichromate, and by readings using the colorimetric method (Quaggio \& Raij, 2001). Undisturbed soils samples were collected in three replications per soil horizon to determine bulk density ( $\rho$ ), soil porosity and soil water retention curves (SWRC).

Bulk density was determined according to the methodology proposed by Blake \& Hartge (1986). Soil macroporosity (macro) was determined using a sandfilled chamber adjusted to a tension of $-5 \mathrm{kPa}$ (Topp \& Zebchuk, 1979) and total porosity (TP) was calculated using $\rho$ and $\rho_{\mathrm{s}}$ by the equation proposed by Vomocil (1965), where TP $(\%)=\left(1-\rho / \rho_{\mathrm{s}}\right) \times 100$. Soil microporosity (micro) was obtained by the difference between TP and macro.

To obtain the SWRC, samples with preserved structure were saturated and subjected to varying potentials $(-1,-3,-5,-8$ and $-10 \mathrm{kPa})$ using a tension table (Topp \& Zebchuk, 1979), and the potentials -33, $-100,-500$ and $-1,500 \mathrm{kPa}$ using the Richards Chamber (Klute, 1986). After complete drainage, the amount of water retained in soil was quantified and the water content calculated. The SWRC were adjusted to the van Genuchten model (van Genuchten, 1980), using software to model soil water retention curves (SWRC, version 2.00) (Dourado-Neto et al., 2000).

Saturated hydraulic conductivity $(\mathrm{Ks})$ was obtained with the Guelph permeameter (Reynolds et al., 1983). To calculate Ks, the single hydraulic head equation proposed by Elrick et al. (1989) was used. Ks was determined at five representative points of the studied transect. Each of these points coincided with the pits used for the morphological characterization and sampling. The $\mathrm{Ks}_{\mathrm{s}}$ for each evaluated horizon was determined based on at least three replications per sampled layer.

\section{Image Analysis}

Undisturbed soil samples were collected from each horizon for micromorphometric image analysis. These samples were air-dried and then oven-dried at $40^{\circ} \mathrm{C}$. Subsequently, the material was impregnated with a mixture of polyester resin (Murphy, 1986), styrene monomer (Castro et al., 2003), fluorescent pigment (Murphy et al., 1977), and a catalyst (Ringrose-Voase, 1991). To increase the impregnation efficiency and facilitate the penetration of resin into the soil, a vacuum system was used (Castro et al., 2003). Once hardened, the impregnated samples were cut and one of the faces polished. The area occupied by pores and pore shape were obtained from the images of each impregnated soil sample, according to two shape indices described by Cooper \& Vidal-Torrado (2005). The pores were quantified from images obtained from the polished face of the impregnated sample. Fourteen random images (photomicrographs) were taken by a digital color camera, at a magnification of $10 x$. The pores were segregated by manual grayscale thresholds for each set of images and viewed in two dimensions. Once the image was obtained, it was converted to a binary code and the pores were individualized and quantified using Noesis Visilog® 5.4 software.

\section{RESULTS AND DISCUSSION}

\section{Morphological characterization}

The predominance of igneous rocks, such as porphyritic granite, define the landscape of the park as mountainous. Associated with the high rainfall rates, the morphogenesis in the middle and upper slopes was classified as accelerated, with frequent soil mass slides and accumulation of material in the footslopes and fluvial channels.

The morphological descriptions and structural analysis showed predominance of Inceptisols along the studied transect with areas of Entisols and hydromorphic soils. Profiles 1, 3 and 4 are the deepest and most developed soils in the transect, reaching a depth of $112 \mathrm{~cm}$. Profiles 2 and 5 were classified as lithic due to a lithic contact between 50 and $100 \mathrm{~cm}$ deep. The lithic contact involves no rock layer, but gravel and boulders possibly transported by mass movements. These mass movements are caused by transportation by water fluxes and the force of gravity. Thus, the soil types and depths at points close to each other may be very different.

A medium-sized subangular blocky structure prevailed in the subsurface horizon (Bi) of all profiles. The organic carbon levels in the soil surface were elevated (34 - $47 \mathrm{~g} \mathrm{dm}^{-3}$ ), decreasing with depth. The OC levels were two-three times lower in the subsurface than in the surface horizons (Table 1). This reduction was probably related to decomposition of the forest litter on the soil surface. 
Table 1. Simplified morphological descriptions, organic carbon content, and soil physical properties of the profiles studied

\begin{tabular}{|c|c|c|c|c|c|c|c|c|}
\hline Horizon & Structure & Texture & OC & $\rho_{\mathrm{s}}$ & $\rho$ & Macro & Micro & TP \\
\hline (Depth $\mathrm{cm}$ ) & & & $g \mathrm{dm}^{-3}$ & - & $\mathrm{n}^{-3}-$ & 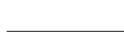 & $-m^{3} m^{-3}$ & \\
\hline \multicolumn{9}{|c|}{ Profile 1 - Typic Dystrudept } \\
\hline $\mathrm{A}(0-16)$ & Med Mod Gra Sub Bl & sandy clay & 34 & 2.40 & 0,98 & 0.22 & 0.38 & 0.6 \\
\hline $\operatorname{Bi1}(16-70)$ & Fn Mod Sub Bl & sandy clay & 14 & 2.50 & 1.38 & 0.14 & 0.31 & 0.45 \\
\hline $\operatorname{Bi} 2(70-110+)$ & Med Mod Sub Bl & clayey & 11 & 2.50 & 1.41 & 0.13 & 0.31 & 0.44 \\
\hline \multicolumn{9}{|c|}{ Profile 2 - Typic Dystrudept } \\
\hline $\mathrm{A}(0-13)$ & Med Mod Gra & sandy clay & 33 & 2.30 & 0.94 & 0.21 & 0.38 & 0.59 \\
\hline $\operatorname{Bi1}(13-51)$ & Med Mod Sub Bl & clayey & 15 & 2.38 & 1.20 & 0.11 & 0.39 & 0.50 \\
\hline $\operatorname{Bi} 2(51-70+)$ & Med Mod Sub Bl & sandy clay & 11 & - & - & - & - & - \\
\hline \multicolumn{9}{|c|}{ Profile 3 - Typic Dystrudept } \\
\hline $\mathrm{A}(0-13)$ & Med Mod Gra & sandy clay & 47 & 2.50 & 1.00 & 0.22 & 0.38 & 0.6 \\
\hline $\operatorname{Bi1}(13-70)$ & Med Mod Sub Bl & clayey & 15 & 2.67 & 1.32 & 0.14 & 0.37 & 0.51 \\
\hline $\operatorname{Bi} 2(70-110+)$ & Med Mod Sub Bl & sandy clay & 8 & 2.67 & 1.26 & 0.15 & 0.38 & 0.53 \\
\hline \multicolumn{9}{|c|}{ Profile 4 - Typic Dystrudept } \\
\hline $\mathrm{A}(0-13)$ & Med Mod Sub Bl & sandy clay & 46 & 2.63 & 1.00 & 0.15 & 0.47 & 0.62 \\
\hline $\operatorname{Bi1}(13-50)$ & Med Mod Sub Bl & sandy clay & 19 & 2.56 & 1.05 & 0.12 & 0.47 & 0.59 \\
\hline $\operatorname{Bi} 2(50-112+)$ & Med Mod Sub Bl & very clayey & 10 & 2.41 & 1.12 & 0.11 & 0.43 & 0.54 \\
\hline \multicolumn{9}{|c|}{ Profile 5 - Typic Dystrudept } \\
\hline $\mathrm{A}(0-8)$ & Fn Mod Gra & sandy-clay-loam & 45 & 2.30 & 1.01 & 0.17 & 0.39 & 0.56 \\
\hline $\operatorname{Bi1}(8-43)$ & Med Mod Sub Bl & sandy clay & 10 & 2.50 & 1.41 & 0.09 & 0.35 & 0.44 \\
\hline $\operatorname{Bi} 2(43-77+)$ & Med Mod Sub Bl & sandy clay & 9 & 2.67 & 1.35 & 0.09 & 0.40 & 0.49 \\
\hline
\end{tabular}

OC: organic carbon; $\rho_{\mathrm{s}}$ : particle density; $\rho$ : bulk density; Macro: macroporosity; Micro: microporosity; TP: total porosity, Med: medium; Fn: fine; Mod: moderate; Gra: granular; Bl: blocky; Sub: subangular.

\section{Hydro-physical characterization}

On average, $\rho$ was $0.97 \mathrm{Mg} \mathrm{m}^{-3}$ (Table 1), and values were lowest in the surface horizons, $(0.94$ $1.01 \mathrm{Mg} \mathrm{m}^{-3}$ ). The low density values may be correlated with high levels of OC and the granular structure of these surface horizons. In the subsurface horizons, $\rho$ was greater $\left(1.05-1.41 \mathrm{Mg} \mathrm{m}^{-3}\right)$ (Table 1$)$. The increased bulk density in the subsurface horizons is probably a natural characteristic of these soils, due to the presence of greater amounts of clay, organized in a more compact subangular blocky structure. The $\rho_{\mathrm{s}}$ values were similar throughout the transect (2.30 $2.67 \mathrm{Mg} \mathrm{m}^{-3}$ ) (Table 1).

The estimated TP ranged from 0.44 to $0.60 \mathrm{~m}^{3} \mathrm{~m}^{-3}$ (Table 1) and was higher in the surface horizons of all studied profiles and lower in the subsurface horizons. In the Bi1 horizon of profiles 2, 3 and 4, TP was higher than in the other Bi1 horizons, which could be related to texture and structure of the horizons of these soils. The reduction in TP was also related to a decrease in macroporosity.

The macroporosity values ranged from 0.09 to $0.22 \mathrm{~m}^{3} \mathrm{~m}^{-3}$, and the lowest values were observed in the subsurface horizons. The microporosity ranged from 0.31 to $0.47 \mathrm{~m}^{3} \mathrm{~m}^{-3}$. Reductions in porosity may diminish the physical quality of the soils, decreasing the rate of water infiltration and oxygen diffusion (Pietola et al., 2005). The critical limit for an adequate occurrence of gas and water exchange is $0.10 \mathrm{~m}^{3} \mathrm{~m}^{-3}$ (Reynolds et al., 2002). Macropores are mainly responsible for oxygen diffusion and water drainage in the profile, while micropores are responsible for water storage in the soil for plant use. The increase of $\rho$ with depth (Table 1 ) was associated with a decrease in TP, an increase of clay content and a reduction of $\mathrm{OC}$.

The soil particle size distribution analysis showed an increase in clay content with depth in profiles 1,4 and 5, while in profiles 2 and 3 the amount of clay increased in the Bi1 horizon and decreased in $\mathrm{Bi} 2$ (Figure 1). The opposite pattern was observed regarding the coarse sand fraction, which decreased with depth in profiles $1,2,4$, and 5 . In profile 3 , coarse sand decreased from horizon $\mathrm{A}$ to $\mathrm{Bi} 1$ and increased from Bi1 to Bi2. The predominant soil texture was sandy clay and clay. These soils contained, on average, $10.7 \%$ silt, and in the sand fraction, more coarse sand than fine sand.

The Ks was higher in the surface horizons than in the subsurface horizons (Figure 1), characterizing 

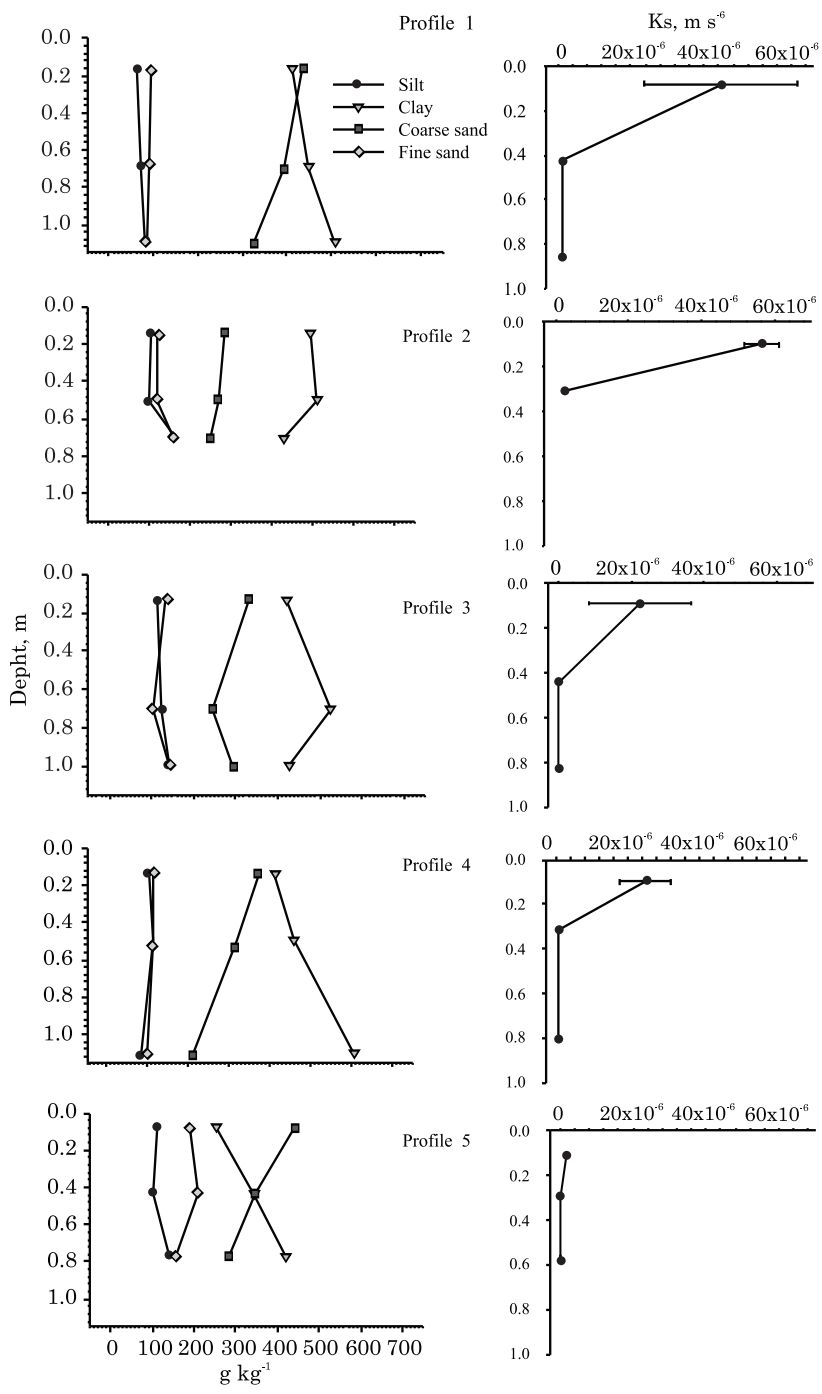

Figure1. Particle size distribution and Ks of soils of the Carlos Botelho State Park, Brazil (bars indicate standard deviation).

the soil as a porous media with intermediate permeability $\left(10^{-6} \mathrm{~m} \mathrm{~s}^{-1}\right)$, according to the classification of Reynolds \& Elrick (1986). The higher $\mathrm{Ks}$ in the surface horizons occurred due to the greater OC content, the higher porosity, the particle size distribution with greater sand content and the granular structure (Glinski \& Lipiec, 1990). The subsurface horizons had lower Ks and permeability classified as intermediate to low. In these horizons, clay contents and $\tilde{n}$ are higher. No clear correlations were observed between Ks and the landscape position, slope and soil depth.

Changes in the shape of the SWRC were related to the pore size distribution, i.e., the steeper the slope, the greater the pore size distribution (Dexter, 2004). In all profiles, the surface horizon had greater moisture values at low water potentials (Figure 2), which means that water is drained quickly and is, therefore, less retained. This result is directly connected to the high proportion of macropores, due to the granular structure observed and the high contents of organic carbon observed in these horizons.

The subsurface horizons had lower moisture contents at lower water potentials $(1 \mathrm{kPa})$ and greater moisture contents at greater water potentials $(1,000$ $\mathrm{kPa}$ ). In these horizons, water drained more slowly and was better retained than in the surface horizons. This phenomenon is related to the structure types in these horizons, the greater density and the greater clay content, resulting in a greater proportion of micropores in the soil matrix, and consequently in greater water retention.

\section{Image Analysis}

The pore number and area of pores (Figure 3) are a function of the class of equivalent diameter (width) and shape (rounded, elongated and complex). The complex pores, with diameters greater than $300 \mu \mathrm{m}$, had a greater participation to the total pore area (\% total area) in all studied profiles (Figure 3 ). This dominance of complex pores was also observed by Juhász et al. (2007). Despite the large area occupied, the total number of this type of pores is low, indicating a high connectivity between the pores. On the other hand, the elongated and rounded pores occupy a small area and have large numbers of pores, independent of the size. This configuration characterizes a pore structure with low connectivity, similar to the evidence observed by Pires et al. (2008).

Most of the observed pores are rounded and elongated within the diameter classes from 30 to 300 $\mu \mathrm{m}$ (Figure 3 ), with no complex pores in these diameter classes. In the $\mathrm{Bi} 2$ horizons from profiles 2 and 3 , elongated pores are observed with diameters greater than $300 \mu \mathrm{m}$. As the pore diameters increased, in all analyzed profiles, the number of rounded and elongated pores decreased, in detriment of the complex pores.

The micromorphometric analysis corroborated the patterns obtained for Ks. In all A horizons of the studied profiles, a high Ks was observed due to the high connectivity of the complex pores (RingroseVoase, 1991). This connectivity decreased with depth because of the decrease in TP (except for profile 2), thereby reducing $\mathrm{Ks}$.

The image analysis showed that the behavior of SWRC in all profiles (except for profiles 2 and 5) was determined by a higher porosity in the surface horizons. OC in the surface horizons contributes to differentiate the SWRC from the other subsurface horizons at lower water potentials. For these water potentials, the change in the SWRC was influenced by pore size distribution (Dexter, 2004) and pore shape. This was explained by the predominantly large complex pores over rounded and elongated pores. 

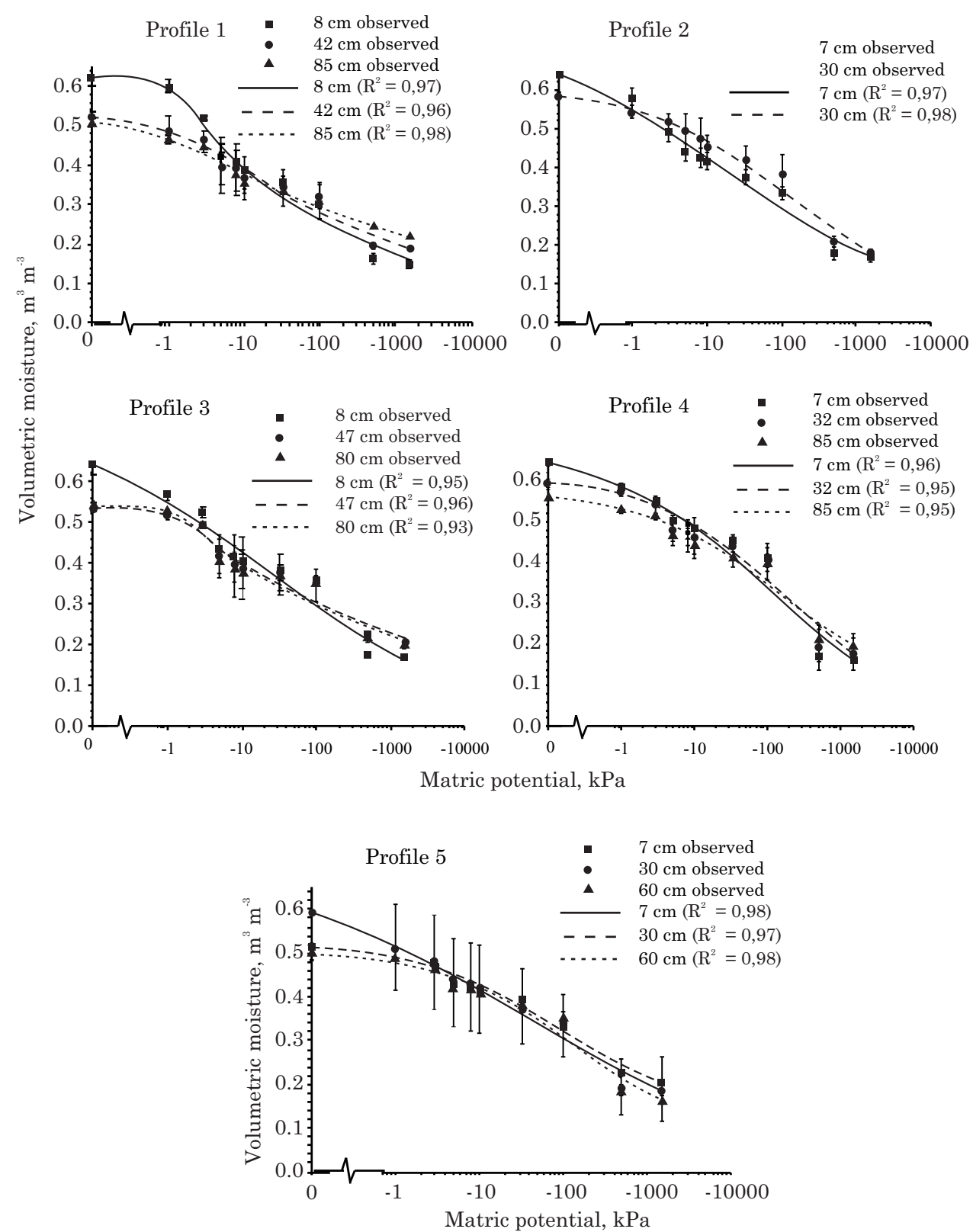

Figure 2. Water retention curves of soils of the Carlos Botelho State Park, Brazil (bars indicate standard error).

\section{CONCLUSIONS}

1. The understanding of soil functioning is fundamental for the restoration of degraded land and of native forests.

2. Soil functioning of the studied transect showed high variability due to changes in the soil hydrophysical properties and topography.

3. Due to landslides, highly rugged topography and low water conductivity in the subsurface, the studied transect was dominated by less developed and shallow soils, despite the climate that promotes accelerated morphogenesis.
4. The high OC content in the surface horizons provided higher $\mathrm{Ks}$, higher porosity, higher water retention at low water potentials and a lower bulk density compared to deeper horizons.

5 , The subsurface horizons, due to their structure and higher clay content, had higher water retention at high water potentials and lower Ks.

\section{ACKNOWLEDGEMENTS}

The authors wish to thank the Fundação de Amparo à Pesquisa do Estado de São Paulo (FAPESP), 

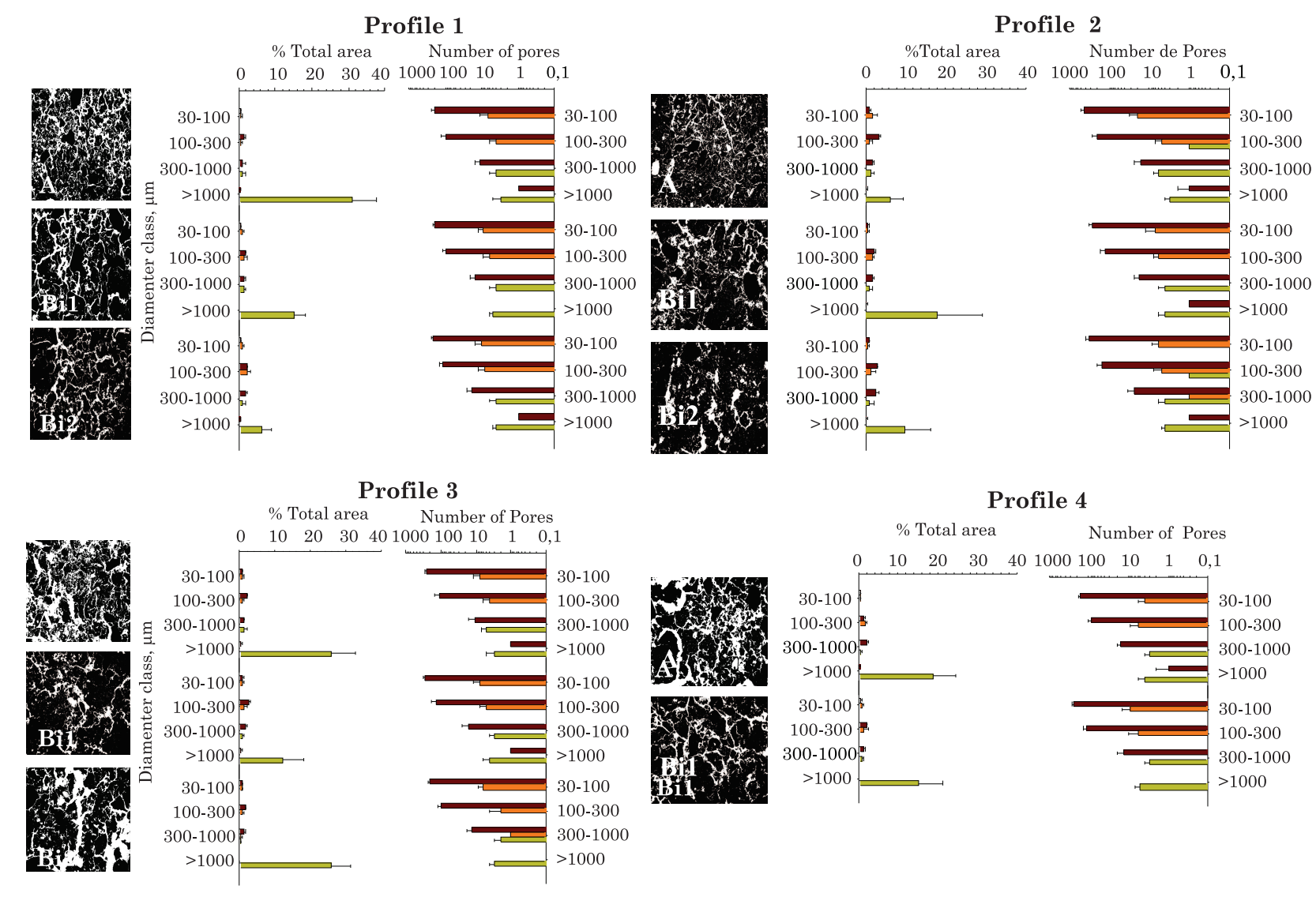

Profile 3

Number of Pores
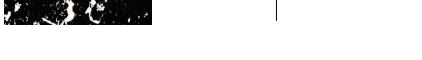

Profile 4
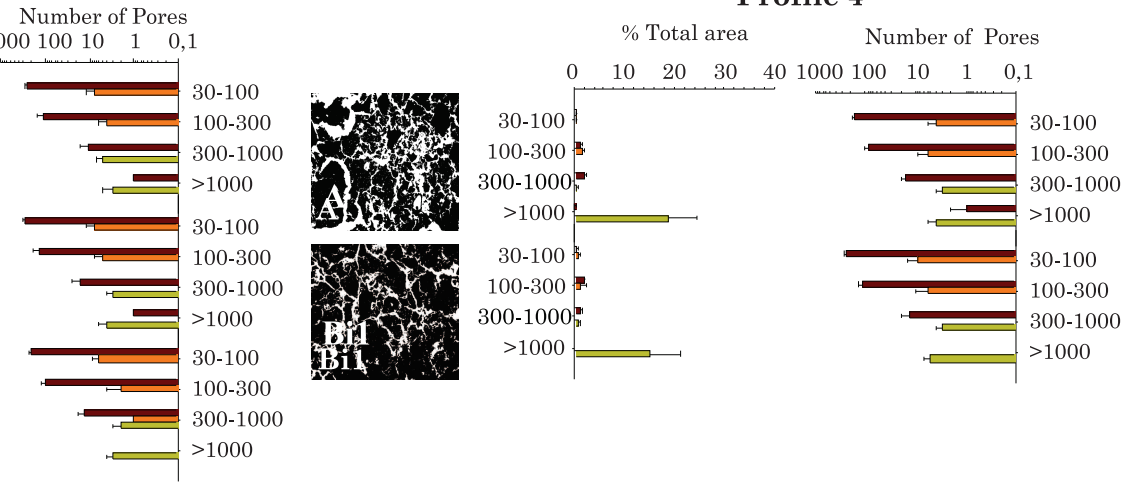

Profile 5

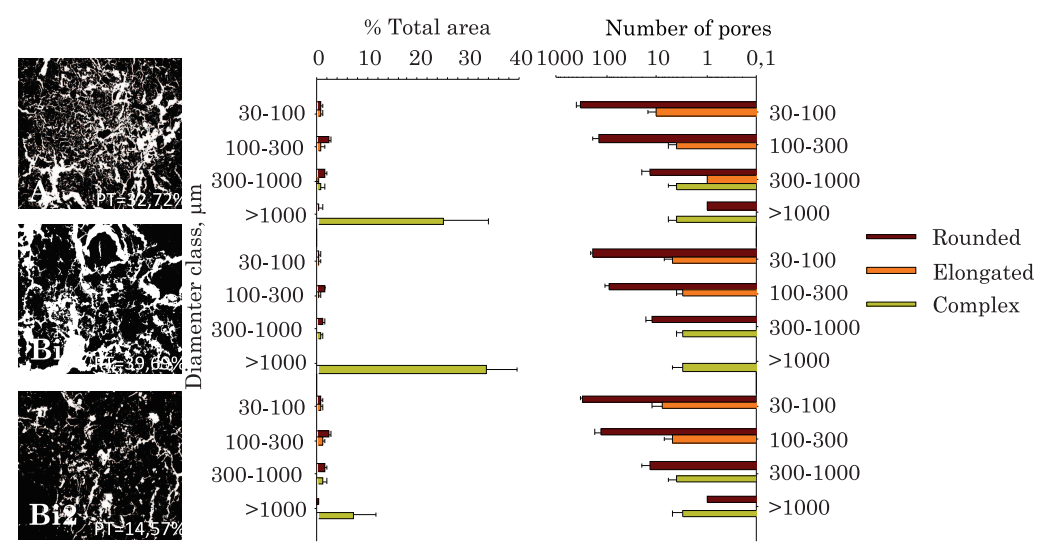

Figure 3. Results of the analysis of images (number of pores, pore percentage of the area and pore shape and size), of the soils of the Carlos Botelho State Park, Brazil.

for the financial support (Process 1999/09635-0) and Conselho Nacional de Desenvolvimento Científico e Tecnológico (CNPq) for the fellowship conceeded.

\section{LITERATURE CITED}

BLAKE, G.R. \& HARTGE, K.H. Bulk density. In: KLUTE, A, ed. Methods of soil analysis; Physical and mineralogical methods. Madison, ASA, 1986. Part 1. p.363-375.
BOULET, R.; CHAUVEL, A.; HUMBEL, F.X. \& LUCAS, Y. Structural analysis and mapping in pedology: I - Taking into account the two-dimensional organization of the soil: Toposequence studies and their contributions to the knowledge of soils. Cah. ORSTOM, Sér. Pédol., 19:309-321, 1982.

CASTRO, S.S.; COOPER, M.; SANTOS, M.C. \& VIDALTORRADO, P. Micromorfologia do solo: Bases e aplicações. In: CURI, N.; MARQUES, J.J.; GUILHERME, L.R.G.; LIMA,. J.M.; LOPES, A.S. \& ALVAREZ V., V.H., eds. Tópicos em ciência do solo. Viçosa, MG, Sociedade Brasileira de Ciência do Solo, 2003. v. 3, p.107-164. 
COOPER, M. \& VIDAL-TORRADO, P. Morphological, micromorphological and hydro-physical characterization of soils with a nitic B horizon. R. Bras. Ci. Solo, 29:581$595,2005$.

DEXTER, A.R. Soil physical quality: Part I. Theory, effects of soil texture, density, and organic matter, and effects on root growth. Geoderma, 120:201-214, 2004.

DIAB, M.; MEROT, P. \& CURMI, P. Water movement in a Glossaqualf as measured by two tracers. Geoderma, 43:143-161, 1988.

DOURADO-NETO, D.; NIELSEN, D. R.; HOPMANS, J. W.; REICHARDT, K.; BACCHI, O. O. S. Software to model soil water retention curves (SWRC, version 2.00). Sci. Agríc., 57:191-192, 2000.

ELRICK, D.E.; REYNOLDS, W.D. \& TAN, K.A. Hydraulic conductivity measurements in the unsaturated zone using improved well analyses. Groundwater Monit. Remed., 9:184-193, 1989.

GEE, G.W. \& BAUDER, J.W. Particle-size analysis. In: KLUTE, A., ed. Methods of soil analysis. 2.ed. Madison, ASA, 1986. Part 1. p.383-411.

HALLAIRE, V.; CURMI, P.; ZILDA, M. \& GRIMALDI, M. Relations between morphology pore and water transfers in saturated conditions or near to saturation. In: CONGRES MONDIAL DE SCIENCE DU SOL, 16., Montpellier, 1998. Proceedings... Montpellier, 1998. CD ROM

GLINSKI, J. \& LIPIEC, J. Soil physical conditions and plant roots. Boca Raton: CRC Press, 1990. 250p.

JUHÁSZ, C.E.P.; CURSI, P.R.; COOPER, M.; OLIVEIRA, T.C. \& RODRIGUES, R.R. Soil water dynamics in a toposequence under Savanna Woodland (Cerradão) in Assis, SP, Brazil. R. Bras. Ci. Solo, 30:401-412, 2006.

JUHÁSZ, C.E.P.; COOPER, M.; CURSI, P.R.; KETZER, A.O. \& TOMA, R.S. Savanna woodland soil micromorphology related to water retention. Sci. Agric., 64:344-354, 2007.

KLUTE, A. Water retention: Laboratory methods. In: KLUTE, A., ed. Methods of soil analysis; Physical and mineralogical methods. 2.ed. Madison, ASA, 1986. Part 1. p.635-660.

KÖPPEN, W. Climatologia: Con un estudio de los climas de la tierra. México, Fondo de Cultura Econômica, 1948. 479p.

LEMOS, R.C. \& SANTOS, R.D. Field soil sampling and description manual. 4.ed. Viçosa, MG, Brazilian Society of Soil Science, 2002. 83p.

MIEDEMA, R. Application of micromorphology of relevance to agronomy. Adv. Agron., 59:119-169, 1997.
MURPHY, C.P. THIN section preparation of soils and sediments. Berkhamsted, A.B. Academic Publishers, 1986. 149p.

MURPHY, C.P.; BULLOCK, P. \& TURNER, R.H. The measurement and characterization of voids in soil thin sections by image analysis. Part I. Principles and techniques. J. Soil Sci., 28:498-508, 1977.

PERROUX, K.M. \& WHITE, I. Design for disk permeameters. Soil Sci. Soc. Am. J., 52:1205-1215, 1988.

PIETOLA, L.; HORN, R. \& HALLA, M.Y. Effects of trampling by cattle on the hydraulic and mechanical properties of soil. Soil Tillage Res., 82:99-108, 2005.

PIRES, L.F.; COOPER, M.; CÁSSARO, F.A.M.; REICHARDT, K.; BACCHI, O.O.S. \& DIAS, N.M.P. Micromorphological analysis to characterize structure modifications of soil samples submitted to wetting and drying cycles. Catena, 72:297-304, 2008.

QUAGGIO, J.A. \& RAIJ, B.van. Determination of $\mathrm{pH}$ in calcium chloride and total acidity. In: RAIJ, B.van; ANDRADE, J.C.; CANTARELLA, H. \& QUAGGIO, J.A., eds. Chemical analysis for assessing the fertility of tropical soils. Campinas, Instituto Agronômico de Campinas, 2001. p.173-180.

REYNOLDS, W.D. \& ELRICK, D.E.A. Method for simultaneous in situ measurement in the vadose zone field saturated hydraulic conductivity, sorptivity and the conductivity-pressure head relationship. Groundwater Monit. Remed., 6:84-95, 1986.

REYNOLDS, W.D.; BOWMAN, B.T. \& DRURY, C.F. Indicators of good soil physical quality: Density and storage parameters. Geoderma, 110:131-146, 2002.

REYNOLDS, W.D.; ELRICK, D.E. \& TOPP, G.C. A reexamination of the constant head well permeameter method for measuring saturated hydraulic conductivity above the water table. Soil Sci., 136:250-268, 1983.

RINGROSE-VOASE, A.J. Micromorphology of soil structure: Description, quantification, application. Austr. J. Soil Res., 29:777-813, 1991.

TOPP, G.C. \& ZEBCHUK, W. The determination of soil water desorption curves for soil cores. Can. J.Soil Sci., 59:19-26, 1979.

van GENUCHTEN, M.T. A closed-form equation for predicting the hydraulic conductivity of unsaturated soils. Soil Sci. Soc. Am. J., 44:892-898, 1980.

VAUCLIN, M.; ÂNGULO-JAMARILLO, R. \& THONY, J.L. Infiltrometer to determine in situ permeability of soil. Geoconfine Rótterdam. Arnould. Barres et Come. Ed., 1993. p.351-356

VOMOCIL, J.A. Porosity. In: BLACK, C.A. ed. Methods of soil analysis. Madison, ASA, 1965. p.299-314. 